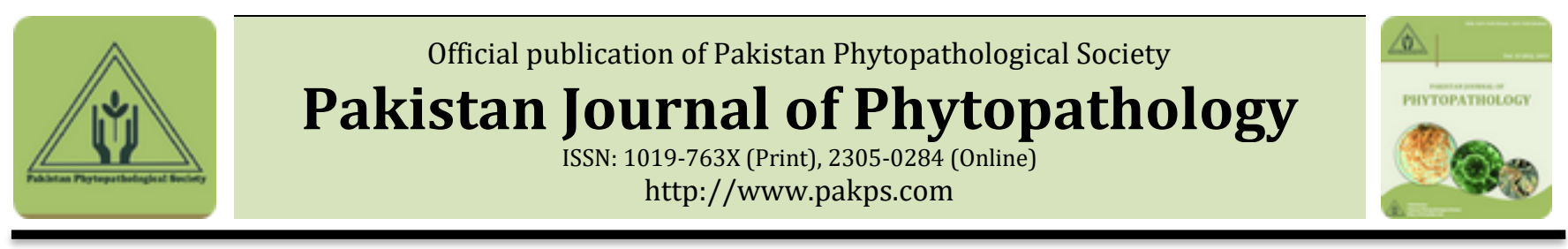

\title{
COMPARATIVE STUDY ON THE GROWTH RATE OF EXOTIC AND LOCAL STRAINS OF VOLVARIELLA VOLVACEA ON DIFFERENT SUBSTRATES
}

\author{
aImran U. Haq*, bSiddra Ijaz, aNabeeha A. Khan, aLuqman Amrao \\ ${ }^{a}$ Department of Plant Pathology, University of Agriculture, Faisalabad- Pakistan. \\ ${ }^{b} C A B B / U S P C A S$ AFS, University of Agriculture, Faisalabad- Pakistan.
}

\begin{abstract}
A B S T R A C T
High cost of animal protein and shortage in availability is deteriorating the quality of health and increasing environmental pollution. The continuous accumulation of organic waste materials is becoming a potential source of environmental pollution. Edible fungi are nature's recycler, which can convert lignocellulosic wastes into protein rich food. This mushroom can be successfully cultivated on several crop residues, certain agricultural and industrial wastes. Five different wild and exotic strains including Vvpk a local strain and Vv436, Vv428, Vv430, Vv422; exotic strains were evaluated for their productivity on the six different crop residues including cotton waste, paddy straw, banana leaves, sugarcane baggase, corn stovers and pulses straw as substrates under different humidity and temperatures. Cotton waste was proved to be the best substrate by producing highest yield followed by paddy straw and banana leaves. The mushroom obtained from cotton waste was of high quality. We may imply that these agricultural waste materials may successfully be used for the production of high quality protein in arid and semi-arid environment, and the hazardous effects of these materials on human health and environmental quality may also be reduced.
\end{abstract}

Keywords: Agricultural wastes; environmental pollution; mushroom; protein; yield

\section{INTRODUCTION}

The advancement in the agricultural technology has to pace with the food production for increasing population of the world and to recycle the agricultural wastes without creating environmental pollution. This is a big challenge for the agricultural scientific community to grow more food by utilizing the waste materials. The cheapest and effective way to convert these wastes in to edible protein is mushroom cultivation (Chang, 1991). Edible fungi are nature's recycler, which can convert lignocellulosic wastes in to protein rich food. Edible mushroom cultivation is one of the most economically viable processes for the bioconversion of many types of lignocellulosic wastes (Buswell et al., 1996). Mushroom

\section{Submitted: May, 16, 2017}

Revised: May, 25, 2017

Accepted for Publication: May, 30, 2017

* Corresponding Author:

Email: imran_1614@yahoo.com

(c) 2017 Pak. J. Phytopathol. All rights reserved. cultivation is a direct utilization of their ecological role in the recycling of industrial and agricultural solid wastes into edible protein, which could be a functional food or a source of drugs and pharmaceuticals. Spent mushroom compost, generated from the mushroom industry, could be exploited as a soil fertilizer and as a bioremediating agent (Chiu et al., 2000).

Currently, millions of tons of agricultural wastes are discarded, burned, neglected and has become a burden because of the destruction and by creating environmental pollution. Waste materials from farms, plantations or factories are used as substrates for the cultivation of the mushrooms. Agro-wastes, produced in abundance in the tropics are cotton waste, sugarcane bagasse, sisal bagasse wheat and rice straw, rice bran, corncobs, bracts of pineapple crown, oil palm waste, grass, sawdust, coffee pulp, coffee bran, coconut fiber water hyacinth plants, Banana leaves coconut husks, orange peel and wood logs mostly are the examples of organic waste used as substrates. Otherwise all these materials are useless byproducts. (Salmones et al., 1996; Bhawna and Thomas, 
2003). Mushrooms have been widely utilized as food and have many health giving properties. Mushrooms are rich source of protein, vitamins including water soluble vitamins, riboflavin, biotin and thiamine, fats, carbohydrates, amino acids including all essential amino acids and essential minerals (Chang and Buswell, 1996; Jiskani, 2001; Buigut, 2002). These are low in fat, carbohydrates and salts (Genders, 1990). Dietary fibers are present in sufficient amount and play an important role for the regulation of digestive tract (Manzi et al., 2001). The edible mushrooms possess unique characteristics in terms of color, taste, aroma and texture, which make them attractive for human consumption (Chang and Miles, 1991). In Pakistan the awareness of mushroom has increased to great extent for the last few years. Among the various mushrooms cultivated in the country, Volvariella volvacea (Chinese mushroom) holds a good promise because most areas of the country are tropical and sub tropical and therefore more suitable for the cultivation of Chinese mushroom. This mushroom can be successfully cultivated on several crop residues like paddy straw cotton waste wheat straw and sugarcane industrial waste (Khan et al, 1982).

Considering the importance of mushroom as a good source of protein and its role in degrading the wastes, especially the agricultural residues, this study was conducted to evaluate different wild and exotic strains for their productivity on different crop residues.

\section{MATERIAL AND METHODS}

Collection and identification of Volvariella volvacea:

Fruiting bodies of $V$. volvacea strain Vvpk (Pakistan) were collected from the botanical garden of University of Agriculture, Faisalabad, Pakistan. The exotic cultures of four exotic strains $V v 436$ (Malaysia), Vv422 (Philippines), Vv428 (Hong Kong) and Vv430 (Taiwan) were imported from mushroom spawn laboratory of Pennsylvania State University, America. Identification of mushroom $V$. volvacea was done by using the methods of Zoberi (1972) and Oso (1975). The mycelium of the five strains including local and exotic of $V$. volvacea was obtained and cultures were maintained on PDA by regular sub culturing during the period of investigation.

Production of spawn: The spawn of five different strains of $V$. volvacea was produced separately by using cotton waste, calcium carbonate and water in the ratio of 32:2:66, respectively, as described by Chang and Miles (2004).

Substrates preparation: Cotton waste, a byproduct of textile mills was collected from industrial area. Paddy straw, lentil straw, corn stovers, Banana leaves and sugarcane baggase were collected from research area of university of Agriculture, Faisalabad, Pakistan. All these agro-wastes except cotton waste were chopped into small pieces with the help of fodder cutter. These chopped agrowastes and cotton waste were soaked in to water for 24 hours and then placed on cemented floor, to remove the excessive water from the wastes to keep the moisture up to $70 \%$. Banana leaves were also chopped with help of fodder cutter. These chopped leaves were soaked in water for 4 hours and then drained later. Lime was mixed @ 5\% to each substrate on dry weight basis. Later on these substrates were covered with polythene for four days for fermentation. Then five beds were made of each substrate and each bed was of $3 \mathrm{~kg}$ weight on dry weight basis of the substrate.

Spawning: The seven days old, prepared spawn of each strain was inoculated on all the substrates. Five replications were made of each substrate and each replication was of 3 $\mathrm{kg}$, of agro-waste on dry weight basis. Gram flour was dusted on each layer of the beds to provide the instant energy to fungus for growth. Each bed was again covered with polythene sheath from all sides till the completion of spawn running.

Regulation of temperature, humidity and light: The temperature and humidity are two critical factors for the spawn running and fructification of the mushroom and were maintained by wetting the flour, thrice in a day. Slight watering was done before the appearance of first fruiting bodies. After this beds were just kept moist by watering Comparison of the mushroom growth on different substrates: Growth of five different strains of Chinese mushroom ( . volvacea) was compared on six substrates i.e., cotton wastes, paddy straw sugarcane baggase, banana leaves, corn stovers and lentil straw. The comparison among the substrates was made by calculating the average yield obtained from each substrate.

Statistical Analysis: Analysis of variance techniques (ANOVA) were applied to analyze the data (Steel et al., 1997) using completely randomized design and means were compared by Duncan's Multiple Range Test (Duncan, 1955).

\section{RESULTS}

The data for the effect of the substrates on $100 \%$ spawn running (Table 1) showed that maximum time was taken by the strains for $100 \%$ spawn running (5.50 days), both on pulses straw and corn stovers, and slowest spawn running was on these substrates, while minimum time was taken for $100 \%$ spawn running on cotton waste by all the strains 
followed by the paddy straw ( 5 days), sugarcane baggase (5.18 days) and banana leaves (5.30 days).This difference of time was non-significant between the corn stovers and Table 1. Effect of substrates on $100 \%$ spawn running of the strains

\begin{tabular}{|c|c|c|c|c|c|c|}
\hline \multirow{3}{*}{ Treatment } & \multicolumn{5}{|c|}{ Strains } & \multirow{3}{*}{$\begin{array}{c}\text { Mean } \\
\text { (Crop x Treat) }\end{array}$} \\
\hline & \multicolumn{5}{|c|}{ Days } & \\
\hline & $\mathrm{Vv}(\mathrm{PK})$ & Vv436 & Vv428 & Vv430 & Vv422 & \\
\hline Cotton waste & $4.20 \pm 0.133$ & $4.40 \pm 0.163$ & $4.80 \pm 0.133$ & $5.30 \pm 0.153$ & $5.70 \pm 0.153$ & $4.88 \pm 0.102 \mathrm{D}$ \\
\hline Paddy straw & $4.40 \pm 0.163$ & $4.50 \pm 0.167$ & $4.70 \pm 0.153$ & $5.70 \pm 0.153$ & $5.90 \pm 0.100$ & $5.04 \pm 0.111 \mathrm{CD}$ \\
\hline Banana Leaves & $4.80 \pm 0.249$ & $4.80 \pm 0.291$ & $4.70 \pm 0.213$ & $5.70 \pm 0.213$ & $6.50 \pm 0.167$ & $5.30 \pm 0.141 \mathrm{AB}$ \\
\hline Corn stovers & $5.00 \pm 0.211$ & $4.80 \pm 0.200$ & $5.40 \pm 0.163$ & $5.60 \pm 0.163$ & $6.20 \pm 0.133$ & $5.40 \pm 0.103 \mathrm{~A}$ \\
\hline Sugarcane baggase & $4.70 \pm 0.153$ & $4.60 \pm 0.163$ & $4.80 \pm 0.133$ & $5.50 \pm 0.167$ & $6.30 \pm 0.153$ & $5.18 \pm 0.113 \mathrm{BC}$ \\
\hline Pulses straw & $4.80 \pm 0.133$ & $5.20 \pm 0.133$ & $5.60 \pm 0.163$ & $5.60 \pm 0.163$ & $6.30 \pm 0.153$ & $5.50 \pm 0.096 \mathrm{~A}$ \\
\hline LSD & & & & & & 0.20 \\
\hline
\end{tabular}

Means sharing similar letter in a row or in a column are statistically non-significant $(\mathrm{P}>0.05)$.

The (Table 2) showed that minimum time taken for pinhead formation was taken on cotton waste (3.02 days) and corn stovers (3.16 days) as compared to the other substrates used for the cultivation. Among the substrates the cotton waste and corn stovers promoted the pinhead formation of the mushroom as compared to the other substrates. The difference of time for pinhead formation by the strains on banana leaves, pulses straw, sugarcane baggase and paddy straw was found to be non significant and this time difference was also non significant between the cotton waste and corn stovers.

Table 2. Effect of substrates on the pinhead formation of strains of V.volvacea

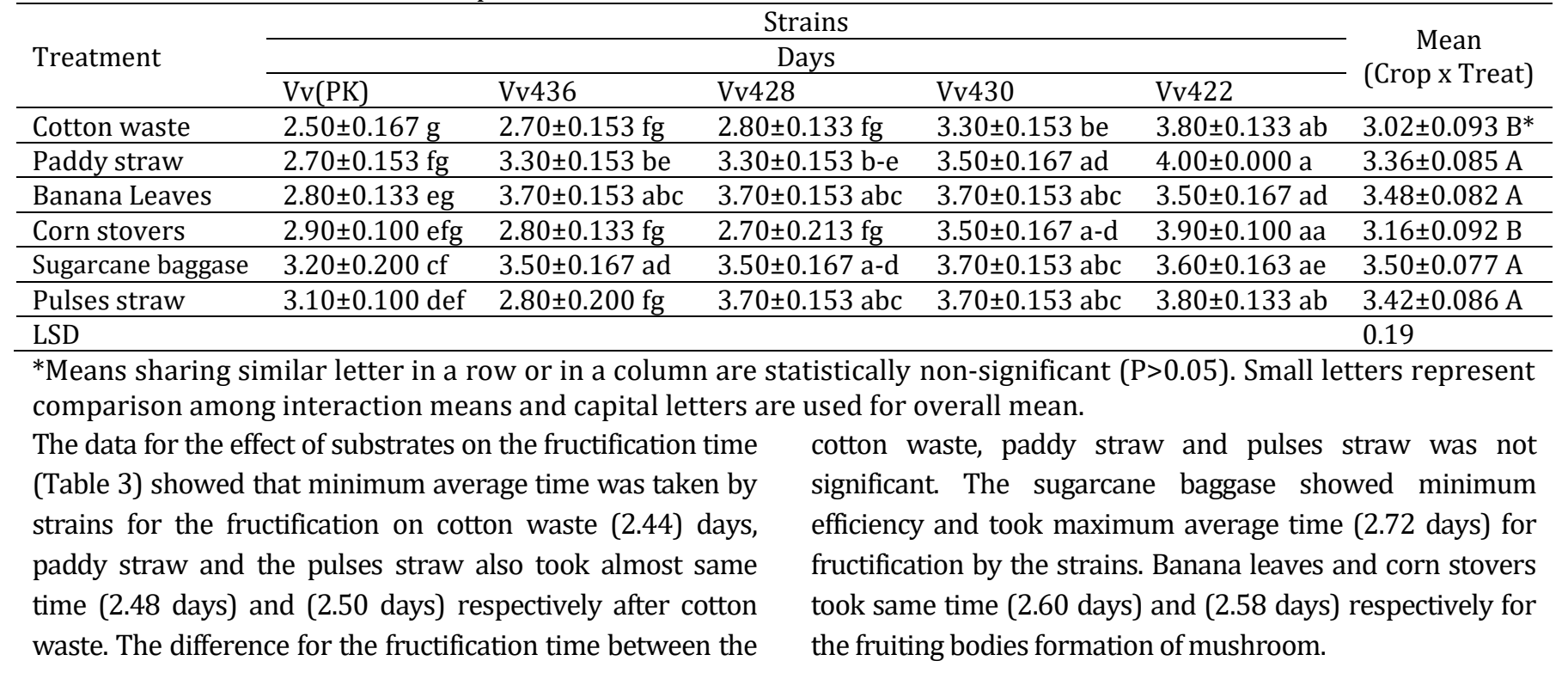

Table 3. Effect of substrates on fructification

\begin{tabular}{|c|c|c|c|c|c|c|}
\hline \multirow{3}{*}{ Treatment } & \multicolumn{5}{|c|}{ Strains } & \multirow{3}{*}{$\begin{array}{c}\text { Mean } \\
\text { (Crop x Treat }\end{array}$} \\
\hline & \multicolumn{5}{|c|}{ Days } & \\
\hline & $\mathrm{Vv}(\mathrm{PK})$ & Vv436 & Vv428 & Vv430 & Vv422 & \\
\hline Cotton waste & $2.20 \pm 0.133$ & $2.20 \pm 0.133$ & $2.50 \pm 0.167$ & $2.70 \pm 0.153$ & $2.60 \pm 0.163$ & $2.44 \pm 0.071 \mathrm{~B}^{*}$ \\
\hline Banana Leaves & $2.50 \pm 0.167$ & $2.40 \pm 0.163$ & $2.60 \pm 0.163$ & $2.70 \pm 0.153$ & $2.80 \pm 0.133$ & $2.60 \pm 0.070 \mathrm{AB}$ \\
\hline Corn stovers & $2.50 \pm 0.167$ & $2.30 \pm 0.153$ & $2.70 \pm 0.153$ & $2.60 \pm 0.163$ & $2.80 \pm 0.133$ & $2.58 \pm 0.071 \mathrm{AB}$ \\
\hline LSD & & & & & & 0.18 \\
\hline
\end{tabular}


The effect of the substrates on the yield of the strains (Table 4) showed that highest average yield of the mushroom was obtained from the cotton waste (734.3g),

Table 4. Effect of substrates on the yield of the strains

\begin{tabular}{lllllll}
\hline \multirow{2}{*}{ Treatment } & \multicolumn{5}{c}{ Strains } & Mean \\
\cline { 2 - 6 } & \multicolumn{5}{c}{ Fresh weight $(\mathrm{g})$} & (Crop x Treat) \\
\cline { 2 - 6 } & $\mathrm{Vv}(\mathrm{PK})$ & Vv436 & Vv428 & Vv430 & Vv422 & \\
\hline Cotton waste & $821.0 \pm 5.09 \mathrm{a}$ & $769.4 \pm 3.91 \mathrm{~b}$ & $734.1 \pm 4.08 \mathrm{c}$ & $696.1 \pm 2.64 \mathrm{~d}$ & $650.7 \pm 2.75 \mathrm{e}$ & $734.3 \pm 8.54 \mathrm{~A}$ \\
\hline Paddy straw & $651.4 \pm 2.93 \mathrm{e}$ & $623.9 \pm 3.16 \mathrm{f}$ & $591.7 \pm 2.20 \mathrm{~g}$ & $567.1 \pm 3.21 \mathrm{~h}$ & $520.1 \pm 1.99 \mathrm{j}$ & $590.8 \pm 6.60 \mathrm{~B}$ \\
\hline Banana Leaves & $547.3 \pm 3.07 \mathrm{i}$ & $523.5 \pm 2.23 \mathrm{j}$ & $496.2 \pm 3.12 \mathrm{k}$ & $443.7 \pm 3.53 \mathrm{l}$ & $405.1 \pm 2.34 \mathrm{n}$ & $483.2 \pm 7.54 \mathrm{C}$ \\
\hline Corn stovers & $291.4 \pm 2.43 \mathrm{~s}$ & $287.2 \pm 3.77 \mathrm{~s}$ & $257.0 \pm 1.89 \mathrm{u}$ & $226.5 \pm 2.82 \mathrm{v}$ & $192.9 \pm 3.83 \mathrm{w}$ & $251.0 \pm 5.49 \mathrm{~F}$ \\
\hline Sugarcane baggase & $318.3 \pm 2.81 \mathrm{r}$ & $343.1 \pm 4.37 \mathrm{q}$ & $319.4 \pm 3.61 \mathrm{r}$ & $273.6 \pm 2.69 \mathrm{t}$ & $231.7 \pm 2.72 \mathrm{v}$ & $297.2 \pm 5.85 \mathrm{E}$ \\
\hline Pulses straw & $439.1 \pm 2.23 \mathrm{l}$ & $417.3 \pm 2.84 \mathrm{~m}$ & $386.3 \pm 3.90 \mathrm{o}$ & $361.0 \pm 2.75 \mathrm{p}$ & $323.4 \pm 3.38 \mathrm{r}$ & $385.4 \pm 5.98 \mathrm{D}$ \\
\hline LSD & & & & & & 3.65 \\
\hline
\end{tabular}

Means sharing similar letter in a row or in a column are statistically non-significant $(\mathrm{P}>0.05)$. Small letters represent comparison among interaction means and capital letters are used for overall mean

\section{DISCUSSION}

The production of agricultural waste, sewage and municipal solid waste in a large quantity is big problem, which the people of both rural and urban areas are facing. Safe disposal of these wastes without polluting the environment is big challenge.

In the present study six different agricultural wastes, cotton waste, rice straw, banana leaves, corn stovers, sugarcane baggase and pulses straw were selected to evaluate these substrates for mushroom production and their recycling in edible biomass. These above mentioned agro-wastes were selected, because all these were abundantly and cheaply available in the fields of Pakistan, round the year. According to Chang and Miles (1991) the Chinese mushroom ( $V$. volvacea) is appropriate for cultivation in tropical regions, the most common edible mushroom in south-east Asia and produced almost all over the world. Each agro- waste was used as a single substrate, no combination of the agro-wastes was used in order to make the mushroom cultivation more easy and to calculate the potential of each agro-waste for mushroom production. These wastes were also selected, by keeping in view the previous experimentation of the different scientists which used variety of agro-wastes for cultivation of $V$. volvacea in the past. Garo (1964) used paddy straw, dried banana stalks and leaves, water hyacinth, wheat straw and sugarcane baggasse. Gupta et al., (1970) tried wheat, maize, barley, oat, pearl millet, and sorghum straw. Chang (1974) cultivated V. volvacea on cotton waste compost in plastic green houses. Khan et al., (1994) tried dried water hyacinth for the cultivation of V. volvacea. Salmones (1996) used 13 agro industrial followed by the paddy straw (590.8g), banana leaves (483.2g), pulses straw (385.4g), sugarcane baggase, (297.2g) and corn stover, (251.0 g), respectively. wastes, banana leaves, bracts of pineapple crown, coconut fiber, coffee bran, coffee pulp, corn cob, corn stover, orange peel, rice bran, rice straw, sisal bagasse, sugarcane bagasse and wheat straw as substrate. Tonial et al., (2000) used industrial residues from cassava and potato starch processing as substrates to produce the edible mushroom Volvariella volvacea. Philippoussis et al., (2001) used three agricultural wastes, i.e. wheat straw, cotton waste and peanut shells. Zervakis et al., (2001) evaluated wheat straw, cotton gin-trash, peanut shells, poplar sawdust, oak sawdust, corn cobs and olive press-cake. Obodai et al., (2003) tried banana leaves, cocoyam peelings and oil-palm pericarp. Belewu and Belewu (2005) evaluated the banana leaves for $V$. volvacea cultivation.

The growth of the mushroom on the substrates was measured in terms of spawn running, pinhead formation fructification and ultimate yield of three flushes from each substrate. In Pakistan the performance of the exotic strains of $V$. volvacea was evaluated for the first time. The results for the spawn running showed that all the strains less time for spawn running, both on the cotton waste and paddy straw as compared to the other substrates. The slow rate of spawn running was observed on the sugarcane baggase and pulses straw. The time taken by the strains for pinhead formation was less on the cotton waste and corn stovers but on the other substrates all the strains took almost same time for pinhead formation and did not showed the significant difference. The highest yield was obtained from cotton waste (734.3g), followed by the paddy straw (590.8g), banana leaves (483.2g). The other data regarding the yield performance of $V$. volvacea in general 
also confirmed the results obtained by the other scientists. Most of the scientists obtained the appreciable yield on cotton waste, paddy straw and banana leaves. Garo (1964) obtained highest yield from the beds of banana leaves as compared, dried banana stalks and leaves, water hyacinth, wheat straw and sugarcane baggase. Gupta et al., (1970) observed low yield on wheat, oat, sorghum, maize, pearl millet and barley straw as compared to the yield obtained from paddy straw. Khan et al., (1994) obtained highest yield from water hyacinth + cotton waste at the rate $1: 1$. Salmones et al., (1996) recorded highest biological efficiency on rice straw. Philippoussis et al., (2001) observed higher growth rate of $V$. volvacea on composted cotton waste substrate. Akinyele and Akinyosoye (2005) reported high fungal growth rate on cotton waste $(98.23 \pm 0.1$ $\mathrm{mm}$ ) and a mixture of rice husk and cotton waste. Zervakis et al., (2001) found on cotton gin-trash the highest linear growth and colonization rates. Obodai et al., (2003) highest production on banana leaves, cocoyam peelings and oil-palm pericarp as substrates. Belewu and Belewu (2005) recorded the total weight of the fruits $2.5 \mathrm{~kg}$, with biological efficiency $15.21 \%$ on banana leaves.It is concluded from this study that with little effort and proper management, we can produce more food by recycling the waste materials to feed the people and also get rid of these wastes without polluting the environment. Mushroom cultivation is fantastic approach to utilize crop residues and to make it more attractive and profitable business.

\section{REFRENCES}

Akinyle, B. and F. Akinyosoye. 2005. Effect of Volvariella volvacea cultivaton on the chemical composition of agrowastes. African Journal of Biotechnology, 4.

Belewu, M. and K. Belewu. 2005. Cultivation of mushroom (Volvariella volvacea) on banana leaves. African journal of Biotechnology, 4.

Bhawna, A. and G. V. Thomas. 2003. Biological efficiency of different Pleurotus species on the leaf stalk biomass from coconut palm. Mushroom Research, 12.

Buigut, S. 2001. Mushroom production in sustainable small-scale farming system-opportunities and constraints: a survey of Uasin Gishu district. Proceedings of the Holticulture seminar on Sustainable Horticultural Production in the Tropics at Jomo Kenyatta University of Agriculture \& Technology, Juja, Kenya 3rd-6th October. pp. 1-
5.

Buswell, J. A., Y. J. Cai, S. T. Chang, J. F. Peberdy, S. Y. Fu and H. S. Yu. 1996. Lignocellulolytic enzyme profiles of edible mushroom fungi. World Journal of Microbiology \& Biotechnology, 12: 537-542.

Chang, S. 1974. Production of the straw-mushroom (Volvariella volvacea) from cotton wastes. Mushroom Journal.

Chang, S. and P. Miles. 1991. Recent trends in world production of cultivated edible mushrooms. Mushroom Journal.

Chang, S. and P. Miles. 2004. Volvariella-A high temperature cultivated mushroom. MushroomCultivation, Nutritional Value, Medical Effect and Environmental Impact (Chang, ST and Miles PG, Eds.) pp: 277-304.

Chang, S. T. 1991. Mushroom biology and Mushroom production. Mushroom J 11: 45-52.

Chang, S. T. and J. A. Buswell. 1996. Mushroom nutriceuticals. World Journal of Microbiology \& Biotechnology, 12: 473-476.

Chang, S. T. and P. G. Miles. 1991. Recent trends in world production of cultivated mushrooms. Mushroom Journal, 504: 15-18.

Chiu, S.-W., S.-C. Law, M.-L. Ching, K.-W. Cheung and M.-J. Chen. 2000. Themes for mushroom exploitation in the 21st century: Sustainability, waste management, and conservation. The Journal of General and Applied Microbiology, 46: 269-282.

Duncan, D. B. 1955. Multiple Range and Multiple F Tests. Biometrics, 11: 1.

Garo, V. M. 1964. A comparative study on the suitability of rice straw, dried banana stalks, banana leaves, wheat straw, water hyacinth and sugarcane bagasse (Volvareiella volvacea Bres. Production. Science J, 1: 130.

Gupta, G., B. Bajaj and D. Suryanarayana. 1970. Studies on the cultivation of paddy straw mushroom (Volvariella volvacea and V. diplasia) in India. Indian phytopathology.

Haq, I. U., S. A. Khan, M. Shoib and M. Iqbal. 2014. First record of Polyalthia Longifolia Leaf Blight caused by Nigrospora sphaerica in Pakistan and its chemical management. 8th international conference on "agriculture, food security and climate change. University of Poocnh Rawalakot.

Jiskani, M. 2001. Energy potential of mushrooms. The Dawn economic and business review: 15-21. 
Khan, S. M., S. M and M. I. Haq. 1994. Studies on the cultivation of Chinese mushroom Volvariella volovacea on water hyacinth. Pakistan Journal of Phytopathology, 6: 130-134.

Khan, S. M., A. Qadir and M. .Ramzan. 1982. Fungal mycelium as a source of protein for animal feed. 21st National Science Conference, pp.28.

Manzi, P., A. Aguzzi and L. Pizzoferrato. 2001. Nutritional value of mushrooms widely consumed in Italy. Food Chemistry, 73: 321-325.

Obodai, M., J. Cleland-Okine and P. N. Johnson. 2003. Use of agricultural wastes as substrate for the mushroom Volvariella volvacea. Tropical Science, 43: 121-124.

Oso, B. A. 1977. Mushrooms in yoruba mythology and medicinal practices. Economic Botany, 31: 367371.

Philippoussis, A., G. Zervakis and P. Diamantopoulou. 2001. Bioconversion of agricultural lignocellulosic wastes through the cultivation of the edible mushrooms Agrocybe aegerita, Volvariella volvacea and Pleurotus spp. World Journal of
Microbiology and Biotechnology, 17: 191-200.

Salmones, D., K. N. Waliszewski and G. Guzmán. 1996. Use of some agro-industrial lignocellulose byproducts for edible mushroom Volvariella volvacea cultivation. Revista Internacional de Contaminación Ambiental, 12: 69-74.

Steel, R., J. Torrie and D. Dickey. 1997. Principles and procedures of statistics: a biometrical approach., 3rd edn (McGraw-Hill: New York).

Tonial, T. M., P. Ashok, M. Chiarello and C. Soccol. 2000. Cultivation of Volvariella volvacea to produce biomass from potato and cassava processing residues by submerged fermentation. Indian Journal of Microbiology, 40: 35-40.

Zervakis, G., A. Philippoussis, S. Ioannidou and P. Diamantopoulou. 2001. Mycelium growth kinetics and optimal temperature conditions for the cultivation of edible mushroom species on lignocellulosic substrates. Folia Microbiologica, 46: 231-234.

Zoberi, M. H. 1972. Bolbitiaceae. Tropical Macrofungi. Palgrave Macmillan UK, pp. 114-116. 